\title{
A „Semmelweis-kutatás” története
}

\author{
Kapronczay Károly dr.
}

\begin{abstract}
Az Orvosi Hetilap alapításának 160. évében a Szerkesztőség felkérésére készített tanulmány.
\end{abstract}

Semmelweis halála után elültek a szakmai viták, mintha megnyugodott volna a nőgyógyász-szülész társadalom. Szép gesztusnak tûnik, hogy Semmelweis Ignác Allgemeine Krankenhausban felállított ravatala előtt - 1865. augusztus 14-én - nemcsak bécsi barátai, hanem ellenfelei is lerótták tiszteletüket. Igaz, itt csak Markusovszky Lajos képviselte a családot és a pesti orvostanári kart, más senki nem jött el Pestról. A pesti és bécsi szakmai és napilapok rövid hírben közülték Semmelweis halálát, részletesebb megemlékezésre éveket kellett várni. ${ }^{1}$ Ettől függetlenül a pesti orvosi kar, az orvostársadalom véleményét mondja ki Lumnitzer Sándor az Orvosegyesület 1865. október 14-i szokásos éves nagyülésén Semmelweis Ignácról: „Fájlaljuk továbbá Semmelweis Ignácz egyetemi tanár, tagtársunk ép oly váratlan, mint gyászos kimúltát. Ô munkás élete, szaktudománybani buzgósága, búvár szelleme s gyümölcsöző eszméi által nemcsak közelebbi hívei, - de azt mondhatni az egész szaktudományos világ színe előtt vívott ki magának történelmi emléket.”2 A későbbi „Semmelweis-kutatók” alaposan átvizsgálták az 1860-as évek közepén rendezett tudományos ülések anyagát, de nem találtak Semmelweis felfedezésére utaló megnyilvánulásokat, de bírálatokat sem.

A csendet Ambró János (1827-1890) kisújszállási városi föorvos törte meg, amikor a Magyar Orvosok és Természetvizsgálók egri vándorgyúlésén (1868. augusztus 25.) az „állatorvosi szakosztályban” Nagykun-Kisújszállás betegségi és halálozási viszonyairól tartott előadást. ${ }^{3}$ Itt részletesen szólt a csecsemőhalandóságról, amelynek leküzdésében nagy szerepet szánt a bábáknak, elsősorban a terhesgondozás, a gyermekágyasok és újszülöttek gondozása területén. A bábaképzés reformját sürgette, amelynek alapján tagja lett a bábaképzés reformját előkészítő bizottságnak. Így került a szakmai közvélemény látókörébe Ambró János, akit 1868-ban a Budapesti Királyi Orvosegyesület levelező tagjának választott és bemutatkozó előadását (1870. január 8-án)

\footnotetext{
${ }^{1}$ Benedek István: Semmelweis és kora. 2. bővített kiadás. Gondolat Kiadó Budapest, 1973

2 Lumnitzer Sándor: Orv Hetil. 1865; 9: 40. szám.

3 Kapronczay Károly: Ambró János emlékezete - halála centenáriumára. Orv Hetil. 1990; 131: 2209-2210.
}

„A szülőházak és Semmelweis tanár tana” címmel tartotta meg. Alapgondolata: a megfelelő tudású és felkészültségű bábák biztosítása mellett szülőházakat kell szervezni, ami biztosítéka lehet a csecsemóhalandóság megállításának. A szülőházak fontosságát a következőkkel bizonyítja: „A szülőházak árnyékoldata, melynek ellenében a gyógyeljárás tehetetlen, de a boldogult Semmelweis tanár által felfedezett aetiologicus mozzanatokból folyó hygiaeniai elvek szigorú alkalmazása a szülőházak létét fenyegető e csapást elhárítani képes. - Ezen, életében félreértett, erélyes meggyőződése egész erejével küzdő tanárnak és érzékenyen sokat bántalmazott nagy búvárszellemnek a tények kérlelhetetlen logikája, a fürkésző ész szigorú következményei, a kísérletek és döntő statistikai adatok bizonyító ereje által megerősített, némiképp más alakban, de lényegében általa hirdetett, egyre nagyobb kiterjedésben nyilatkozó, s remélyleni lehet, hogy nem sokára teljes diadalra vergődő tana megmentette és megmenti százezrek, milliók életét, s a szülőházak létét." Semmelweis igazát saját gyakorlatából hozott adatokkal is bizonyította és a profilaktikus elvek alapján javasolta a szülőházak szakmai munkájának a megszervezését. Végezetül felhívta minden orvos figyelmét, hogy „tanulmányozni kell Semmelweis munkáját, hirdetni minden tanszékből tanát, hogy minden orvos egész kiterjedésében, correcte ismerje azt". A Az előadáshoz Fleischer József (1829-1877) úgy szólt hozzá, hogy Ambró munkáját az Orvosegyesület nyomtassa ki. Ambró Semmelweisszel kapcsolatos álláspontjával Poór Imre - az örök ellenkező és a Gyógyászat föszerkesztője - egyetértett, de megjegyezte, hogy a „gyermekágyi láznak az állati anyag felszívatásán kívül egyéb oka is van, különben miképpen lehetne megfejteni a falvakban, tiszta magánházaknál előforduló gyermekágyi láz-eseteket?”

Ambró a későbbiekben is következetesen - különböző szakmai fórumokon tartott előadásaiban - kiállt a Semmelweis-doktrína mellett, amelynek következtében Fleischer József 1872-ben az Orvosegyesületben megtarthatta Semmelweis-emlékelőadását. Ambrót a Pozsonyban

${ }^{4}$ Ambró János 
felállított bábaképző intézet igazgatójává (1873. január 1.) nevezték ki.

1872-ben Semmelweis Ignác felett az emlékbeszédet - mint már említettük - Fleischer József tartotta, akit a szakirodalom a Semmelweis-doktrína legszilárdabb követőjének és támaszának tart. Fleischer 1853. június 13án kapta meg orvosi diplomáját a pesti orvosi karon, majd 1854 áprilisában kinevezték tanársegédnek a Birly Ede Flórián (1787-1854) vezette szülészeti klinikára. Itt kötelezte el magát végleg a nőorvoslás mellett. Egy év múlva, Birly halála után, Semmelweis lett a klinika professzora. Birly a gyermekágyi láz okát a levegóben terjedő titokzatos kórban látta, ezért a Semmelweis mellett eltöltött évek döntô jelentôségúek Fleischer számára: alapjaiban megismerte Semmelweis kutatásait, a megelőzés jelentőségét és megértette a Semmelweis-doktrína lényegét. Tanúja lehetett az első, Semmelweis által végzett császármetszésnek (1857. március 19.), amelyről ő írt beszámolót az Orvosi Hetilapban. Ott volt az 1863 januárjában Balassa Jánossal végzett petefészekmütétnél is. Semmelweis, a gyermekágyi láz okát bizonyító statisztikáját Fleischer segítségével készítette el, majd az Aetiológia megjelenése után Fleischer írta meg az első méltatást és a könyv bővebb ismertetését 1861-ben a Gyógyászat címü folyóiratban. Az elmondott Emlékbeszéd, a felismerés tényszerü leírása és elemzése mellett, valóban hitvallás volt Semmelweis életmúve és munkássága mellett. Nem véletlenül hivatkoztak sokszor Fleischerre, aki 1869-től a Rókus Kórház szülészeti osztályának élére került. Itt Semmelweis tanításának szellemében dolgozott: a szülőnőket külön helyezte el a nőgyógyászati betegektől, a rákos betegeket más épületbe helyeztette el. Szigora még Semmelweisen is túltett, osztályán több éven át a gyermekágyi lázban megbetegedettek aránya egy százalék alatt maradt. Kiváló operatőr volt, sebfertőtlenítési eljárások vonatkozásában még a merésznek tûnő eljárásoktól sem riadt vissza. Életének utolsó éveiben elhatalmasodó betegsége akadályozta meg szakmai tapasztalatainak leírásában.

\section{A Semmelweis-kutatások kezdete}

Ezek hátterében elsősorban Fleischer hatását fedezhetjük fel. Segédorvosa, az 1867-ben orvossá lett Beretzky Endre (1842-1921) - a későbbi kőbányai ismert körorvos, református presbiter, 1890-től a Paula Szülőotthon első igazgatója - kétéves németországi tanulmányúton vett részt. Elsősorban a szülészet-nőgyógyászati osztályokon képezte tovább magát és „semmelweisi szempontokból” vizsgálta a kórházi viszonyokat. Rendszeresen úti beszámolót küldött az Orvosi Hetilapnak. Tíz évvel az első „nyílt levél” megjelenése után írta, hogy „Semmelweis tanár már sok hódítást tett. Néhol csak hallgatva követik, másutt vezérnek nevezik őt. A legnagyobb örömmel írhatom, hogy olyan híres egyetem, mint a berlini, azon elvek szerint halad ma, melyeket eleinte kételylyel fogadott." Nagy hatást gyakorolt Beretzkyre Martin professzor, aki elrendelte a vizsgálatok előtti szigorú kézmosást kálium-permanganátos oldattal, valamint megtiltotta a boncoláson részt vett orvosoknak a 24 órán belüli betegvizsgálatot. Sajnos a legtöbb helyen nem vezettek betegstatisztikát, így a gyermekágyi lázzal kapcsolatban csak hozzávetőleges adatokat kaphatott. A semmelweisi tanok érvényesülését tapasztalta Koppenhágában, Boroszlóban, Drezdában, Halléban. Az utóbbi helyen, a szülészeti klinikán megtiltották a gyakornokoknak a boncoláson való részvételt. ${ }^{5}$

Ugyancsak Fleischer segédorvosa volt Liebmann Mór (1842-1908) - a későbbi neves szülész, a Budapesti Orvosi Kaszinó egyik alapítója, majd elnöke -, aki 1872ben mehetett a Schordan-féle egyetemi ösztöndíjjal európai tanulmányútra. Szintén az Orvosi Hetilapnak írt úti beszámolóban mutatta be - többek között - a semmelweisi tanok érvényesülését, illetve a gyermekágyi lázzal kapcsolatos helyzetet. Liebmann megfordult Bécsben, Münchenben, Würzburgban, Heidelbergben és Párizsban. Bécsben Braun és Spath klinikáján járva megállapította, hogy „a bécsi iskolán a boldogult Semmelweis tanár által felállított fertőzési tan már általánosan el van ismerve". Heidelbergben Lange klinikáján is hasonlót tapasztalt. Érdekes tapasztalatai voltak Párizsban és Liege-ben, ahol jól felszerelt kórházak szülészeti osztályain általában $2 \%$ alatt tartják a gyermekágyi lázban elhaltak arányát. Igaz, amikor emelkedik a halálozás száma, az osztályokat átmenetileg bezárják, a betegeket fokozatosan hazaküldik, velük kapcsolatban a kórháznak már nincs felelőssége. Csak akkor nyitják meg újra a szülészeti osztályokat, amikor alapos takarítás, teljes ágynemúcsere és szellőztetés után biztonságosnak ítélik a helyzetet.

Beretzkyhez és Liebmannhoz hasonlóan a Rókus Kórházban, a Fleischer vezette osztályon kezdte nőorvosi pályáját Bruck Jakab (1845-1902) is - 1875-től majd az Erzsébet-fürdő főorvosa, jeles balneológusa. Diplomáját 1870-ben szerezte Pesten, 1870-1874 között Fleischer segédorvosa. Az ő hatására fordult a semmelweisi életmű tanulmányozása felé, 1878-ban pedig ő mondta az emlékbeszédet Fleischer felett, külön kiemelve, hogy a Rókus Kórház szülészeti osztálya teljesen a semmelweisi rendszabályok szerint múködik. Bruck legjelentősebb és legmaradandóbb munkája - Semmelweis Ignácz Fülöp cím alatt - 1885-ben látott nyomdai napvilágot (német változata 1887-ben). A kis kötet teljességében dolgozza fel Semmelweis életrajzát, értékeli életmúvét, annak minden állomását és vonatkozását. Nem véletlen, hogy a magyar és külföldi Semmelweis-kutatók kutatásainak kiindulópontja lett.

Bruck Jakab nemcsak a gyermekágyi láz Semmelweiszszel kapcsolatos vonatkozásait dolgozta fel, hanem szakirodalomi kutatással a 18. századtól kíséri nyomon a problémát. Statisztikai alapon vizsgálja meg az európai

Beretzky Endre: Orv. Hetil. 1876; 24. szám 
helyzetet, a legjelentősebb - Berlin, Bécs és a többi német, valamint francia, angol - egyetemek helyzetét, bó szakirodalmi hivatkozásokkal. Figyelme fóleg a bécsi szülészeti klinikákra összpontosul, a gyermekágyi láz kórokozójával kapcsolatban a szakvélemények elemzését is megadja. Semmelweis tevékenységét a legrészletesebben kíséri végig, majd azokat a vitákat értelmezi, amelyek Semmelweis megállapításával, a megelőzés módszertanával robbantak ki. Ezzel az alapossággal elemzi Semmelweis szakirodalmi tevékenységét, az első publikációktól a nyílt levelekig, külön figyelmet szentelve az Aetiológia címú munkára. Munkájában teret adott a Semmelweis halála utáni húsz év eseményeinek, külön szólva Lister sebkezelési módszeréról, az ún. prioritási vitáról is. Bruck munkája valóban a Semmelweis halálát követő húsz év eseményeinek részletes összefoglalása és értékelése.

Ambró fellépése után megnövekedett a Semmelweis mellett kiállók tábora, akik közül kiemelkedett Fleischer József - munkatársai közül kerültek ki Semmelweis meggyőződéses hívei, az életmü szakszerü leírói. Fleischer munkahelye, a Rókus Kórház mellett, a kolozsvári orvossebészeti intézetben, majd 1873-tól a pozsonyi bábaképző intézetben a gyakorlatban is megvalósították a Semmelweis-féle elveket, és a pesti szülészeti klinikán is, Kézmárszky Tivadar fellépéséig, legfeljebb a megelőző rendszabályok szigorú betartásában voltak hiányosságok. A bábaképzés ügye is Semmelweis nevével összekapcsolva indult el a korszerű fejlődés útján.

A Semmelweis-doktrína igaza mellett foglalt álláspontot Alfred Hegar (1830-1914) freiburgi szülészprofeszszor, jeles nőorvos, számos könyv szerzője, aki már az 1860-as évek nagy vitája idején is kiállt Semmelweis mellett. 1882-ben 50 oldal terjedelmú könyvében - Ignaz Phil. Semmelweis. Sein Leben und seine Lebre - plasztikus képet rajzolt Semmelweis egyéniségéről, felfedezéséről, küzdelméről, sőt tudományos értékelést ad a gyermekágyi láz kórtanáról és a korabeli tudományos értékelés hibáiról. Hegar úgy érezte, hogy az 1870-es évek derekán igazságtalanság történt Semmelweis emlékével, amikor az európai orvosi közvélemény Pasteur és Lister nagyságának ünneplése mellett megfeledkezett Semmelweis érdemeiről. Minthogy nem ismerte a magyar viszonyokat, így korábbi tanítványától, Tauffer Vilmostól (1851-1934) kért adatokat Semmelweisról. Tauffer lelkiismeretesen járt el, kikérte a szemész Hirschler Ignác (1823-1891) segítségét, aki írásban foglalta össze - saját emlékeiból - Semmelweis jellemrajzát. Talán Hegar munkája az egyetlen, amely elóítéletektől mentesen, tárgyilagosan szól Semmelweis életmúvéről. Ugyanígy szól Semmelweis betegségérôl és haláláról. Kimondta, hogy Semmelweis nem elmebajban, hanem gennyvérüségben halt meg; megértéssel vázolta a betegség következtében megváltozott Semmelweis magatartását.

Hegar munkájának megjelenése siettette Bruck 90 oldalas Semmelweis könyvének kiadását is, ami valamennyi addig megjelent munkánál alaposabb, forrásmú. Ezek a munkák csak előkészítették a négy évvel később kezdődő igazi Semmelweis-kultuszt, amelyet Semmelweis hamvainak exhumálása idézett elő.

\section{A Semmelweis Emlékbizottság munkássága}

A Semmelweis halálát követő két évtizedben - ezt bizonyítják Beretzky, Liebmann és Hegar felmérései - alapvető szemléletváltozás következett be az orvostársadalomban. Semmelweisnek a statisztikán kívül egyéb tudományos bizonyítékot nélkülöző előadásmódja nem tudta meggyőzni kora szülészeit a „bomlott szerves anyagok" fogalmával kapcsolatban. Nem mellékelt vegyi vizsgálatokat, mikroszkópos készítményeket sem. Semmelweis kortársai kitartottak a gyermekágyi láz epidemikus eredete mellett. A fiatalabb generációk számára idővel megmagyarázhatatlanná váltak a miazma, a genius epidemicus és a hasonló fogalmak, amelyekre végül tudományos magyarázatot, főleg a „bomlott szerves anyag" vonatkozásában a bakteriológia adott. A gyermekágyi láz bakteriológiai magyarázatának gondolata érdekes módon a Karl Braun vezette bécsi I. sz. szülészeti klinikán született meg: Karl Mayerhofer, a gyermekágyasok méhüregében vibriószerû képződményt talált, amelynek kórokozó szerepet tulajdonított. Kezdetben arra gondolt, hogy a kórterem levegőjében lebegő vibriók közvetítik a betegséget, de csakhamar rájött, hogy a vizsgáló orvos keze viszi a vibriókat a női szervezetbe. Ekörül is vita támadt, Waldeyer és Orth a gyermekágyasok vérében láncszerüen elrendeződött gömbölyü baktériumokat, streptococcusokat találtak, amelyeket Pasteur 1879-ben a gyermekágyi lázas betegek szerveiból és véréből kitenyésztett. Ezzel végleg tisztázódott a gyermekágyi láz kóroktana. Pasteur közleményében sajnos nem említette Semmelweis nevét, felismerését. Ennek is „köszönhető", hogy két évtizednek kellett még eltelnie, egy új orvosnemzedéknek kellett eljönnie, hogy Semmelweis igaza mindenki előtt érthetővé váljon.

A „Semmelweis-kutatás” második nagy korszaka 1891-ben kezdődött, amikor Semmelweis hamvait a schmelzi temetóből Budapestre hozták és a Kerepesi temetőben, a Walther-család sírboltjában újra eltemették. A következő két hónapban az egyetem orvosi karán és az Orvosegyesületben egy-egy emlékbizottság alakult, amely Semmelweis-emlék végrehajtó bizottság néven egyesült, 18 évig múködött. A bizottság nagy terveket állított maga elé: nemzetközi gyưjtésből szobrot állítani, díszsírt faragtatni, emléktáblával ellátni Semmelweis tabáni szülőházát, egy kötetben kiadni Semmelweis összes munkáját, nemzetközi ösztöndíjat alapítani Semmelweis nevével, Semmelweis emberbaráti intézményt szervezni. A lelkesedés sajnos nagyobb volt, mint az adományok összegyújtése, így a terveket csak fokozatosan lehetett megvalósítani.

Elsőnek a díszsírhely valósult meg, amelyet az 1894. évi budapesti VIII. nemzetközi közegészségügyi és demográfiai kongresszus alkalmából avattak fel. A kong- 
resszuson Kézmárszky Tivadar (1842-1902), szülésztanár mondott ünnepi emlékbeszédet Semmelweis felett, majd a prágai higiénikus, Ferdinand Hueppe/Hüppe (1852-1938) lelkes előadást tartott a „német” Semmelweis felfedezéséről. Idézte Listert is, aki elismerte Semmelweis prioritását a sebfertőzés elhárításának területén. Még ebben az évben Doby Jenő elkészítette Semmelweis arcképének rézmetszetét. Ettől függetlenül nagyon lassan haladt a program megvalósítása, a közadományozás kevésnek bizonyult a Semmelweis-szobor elkészítéséhez.

1905-ben megint az történt, ami az 1880-as évek elején: a bécsi Hartleben Kiadó megjelentette Fritz Schürer von Waldheim (1866-1935), a bécsi sebészeti klinika munkatársának, orvostörténésznek Semmelweis-monográfiáját: Ignaz Philipp Semmelweis, sein Leben und Wirken, Urteile der Mit- und Nachwelt. Ha nem is válaszként, de 1906-ban látott nyomdai napvilágot Győry Tibor (1869-1938) orvostörténész szerkesztésében Lipcsében a Semmelweis összegyüjtött munkái magyarul, Győry előszavával és bevezetố tanulmányával. Nem sokkal késő́bb az Akadémiai Kiadó gondozásában németül is megjelent az előbbi munka. A Semmelweis-kiadványok és -rendezvények motorja Győry Tibor volt, akiról Benedek István 1965-ben a következőket írta: „Győry Tibor inkább apostola volt Semmelweisnek, mint kutatója. Harciasan kiállt érte, ha meg kellett védeni. Fóként magyarságát és prioritását védelmezte, miként ez a század első éveiben oly divatos volt."

$\mathrm{Az}$ ünnepi sorozatot egy nemzetközi Semmelweiskonferencia vezette be, amelynek csúcspontja az Erzsébet téren a Semmelweis-szobor - Stróbl Alajos munkája - felavatása lett, valamint emléktáblával jelölték meg Semmelweis Ignác tabáni szülőházát. Az 1898-ban alapított Budapesti Orvosi Kaszinó - Tauffer Vilmos javaslatára - az 1870-es években jelentős Semmelweis-kutatásokat végző Liebmann Mór elnöksége idején - Semmelweis-emlékserleget alapított, a kitüntetettnek viszont emlékelőadást kellett tartani. ${ }^{7}$

A megemlékezések a sajtónak is külön „feladatot” adott: beszélgetést közöltek Semmelweis Ignác özvegyével, elsősorban a halál körülményeit vizsgálták. Ekkor került az érdeklődés középpontjába a zirci születésú Semmelweis Károly (1871-1934) szülész-nőgyógyász, a zirci kórház fóorvosa, aki 1895-ben szerzett orvosi diplomát a pesti orvosi karon, majd három esztendőt töltött - sebész- és nőorvosi szakorvosi oklevél megszerzése miatt - a Rókus Kórházban. Semmelweis Károly büszke volt, hogy ugyanazon a folyosókon és lépcsőkön járhatott, mint nagy névrokona. Nem vallotta magát vérrokonnak, de ettól függetlenül sokan a zirci Semmelweis családdal való kapcsolatot keresték. /Sokszor szerepelt a

\footnotetext{
${ }^{6}$ Benedek István

7 Kapronczay Katalin, Kapronczay Károly: Semmelweis Ignác emlékezetére 150 évvel halála után. In: Monos Emil (szerk.) Semmelweis Kiadó, Budapest, 2015; pp. 182-188.
}

sajtóban a zirci származású Semmelweis Mátyás ácsmester neve is, aki Budapest Belvárosának átépítésénél sok épület tetőszerkezetének munkálatait irányította. Talán ez késztette Horváth Konstantin zirci cisztercita paptanárt, hogy könyvformában megjelentesse a zirci Semmelweis-család másfél évszázados történetét.

\section{Ünnepek után, ünnepek előtt}

Az első világháború tíz évre befagyasztotta, a második teljesen megszüntette ezeket a Semmelweis-ünnepségeket. Viszont 1928-től hagyománnyá vált, hogy július l-jén a pesti orvosi kar dékánja, a tanári kar, a tudományos társaságok vezetői megkoszorúzták Semmelweis Ignác Erzsébet téri szobrát, amely alkalmat adott a megemlékezésre. 1938-ban játékfilmet készítettek Semmelweisről. 1948-ban, a magyar szabadságharc centenáriumán - ahogy a kor megkívánta - „megalkották” a forradalmár Semmelweis alakját, abban a filmben, amelyben Apáthy István ragyogóan megformálta Semmelweist, de a bécsi forradalmi jelenetek félresikerültek. Fekete Sándor (1885-1972) professzor, jeles nőgyógyász, a Semmelweis Orvostörténeti Múzeum első igazgatója, az 1960-as évek végén hosszú tanulmányban ${ }^{8}$ cáfolta az elóbbi képet. Naptári pontossággal feltárta a bécsi „forradalmi napok” történéseit: ezek a napok és hetek voltak Semmelweis szakmai életében a bizonyítási korszak, amikor figyelme csak a gyermekágyi láz kórtanára összpontosult.

Hidvégi Jenő Semmelweis életérôl, munkásságáról címú könyve 1950-ben jelent meg, amely inkább az ismeretterjesztés körébe tartozik, csakúgy, mint Kertész Róbert Az anyák megmentöje, Semmelweis Ignác életregénye (1941) ismeretterjesztő füzete.

Semmelweis halálának századik évfordulójának tiszteletére az UNESCO az 1965. évet Semmelweis Évnek nyilvánította. Ezen apropóból a Magyar Tudományos Akadémia nemzetközi részvételű ünnepi ülést szervezett, amelyre a világ minden tájáról érkeztek előadók. Az ünnepi ülés során avatták fel Semmelweis szülőházában a Semmelweis Orvostörténeti Múzeumot, kertjében alakították ki Semmelweis hamvainak végső nyughelyét. Erre az alkalomra jelentette meg az Akadémiai Kiadó Gortvay György és Zoltán Imre Semmelweis élete és munkássága címú könyvét, amely hatalmas jegyzetapparátussal és szakirodalmi mutatókkal kíséri végig Semmelweis életét, munkásságának mindegyik állomását, betegségének és halálának körülményeit és a Semmelweis-doktrína történetét. Később a könyv angol nyelven is megjelent. ${ }^{9}$

Az évforduló kapcsán - szakfolyóirati szinten - számos Semmelweis-kutatónál az érdeklődés középpontjába Semmelweis betegsége és boncjegyzőkönyve került.

\footnotetext{
${ }^{8}$ Fekete Sándor

Gortvay György, Zoltán Imre: Semmelweis élete és munkássága. Akadémiai Kiadó, Budapest, 1966.
} 
Még 1865-ben, az Orvosi Hetilap leközölte Scheuthauer Gusztáv és Meyert Tivadar boncjegyzókönyvét ${ }^{10}$, amely mindig témája lett a Semmelweisszel foglalkozó kutatásoknak. Mindketten jelen voltak Semmelweis felboncolásánál, feltehetően a kórboncnok professzor, Rokitanszky engedélyével adtak át egy szöveget az Orvosi Hetilapnak. Az orvostörténetírás ezt hiteles szövegnek vélte, soha senki nem kételkedett ennek eredetiségében. Ez ugyan nem közölt külsérelmi sérülésekre vagy a paralízisre utaló leírásokat. 1944-ben a bécsi egyetem orvostörténeti intézetében olyan tanulmány látott nyomdai napvilágot, amely egy-két ponton ellentétes a Scheuthauerféle leírással. Erre az ellentmondásra kerestek többen választ, de ehhez szükség lett volna a Bécsben őrzött eredeti boncjegyzókönyvre, legalábbis megtekintésére. A Bécsi Orvostörténeti Intézet - ahol őrzik a Semmelweisre vonatkozó összes iratanyagot - mereven elutasított minden érdeklődött, az iratot elveszettnek mondta. Az 1950-es években Darvas István - több kiváló Semmelweis-tanulmány szerzője - megkísérelte felderíteni az ellentmondásokat, ő is eredeti formában akarta tanulmányozni a boncleírást, de sikertelen lett minden próbálkozása. Kudarc várt Haranghy László és Regöly-Mérei Gyula hasonló próbálkozásaira is. Végül az 1865. évi és az 1944. évi alapvetésnek számító nyomtatott szövegekből vontak le következtetéseket Semmelweis betegségével és halálával kapcsolatban. Amikor Semmelweis maradványait 1963-ban exhumálják a Kerepesi temetőben, Bartucz Lajos, ${ }^{11,12}$ Haranghy László ${ }^{13}$ és Regöly-Mérei Gyula $^{14,15}$ külön-külön is, majd együtt is megvizsgálta a csontmaradványokat. Erről külön jegyzőkönyvet írtak alá, bár nem tudták megmagyarázni (csak feltételezéseket közöltek) a már említett két korábbi publikáció ellentmondásaival kapcsolatban. Ekkor válik terebélyessé a Semmelweis-irodalom: feldolgozzák Semmelweis pesti és bécsi tanulmányainak körülményeit, kapcsolatait más egyetemekkel, a pesti orvosi iskolával, stb. Az egyik csúcs Benedek István Semmelweis és kora címú, 1973-ban meg-

${ }^{10}$ Scheuthauer Gusztáv, Meyert Tivadar: Semmelweis Ignácz tanár holt testének vizsgálata. Orv Hetil. 1865; 9: 763-768.

11 Bartucz Lajos: Semmelweis négyszeri exhumálása. Természettudományi Közlöny, 1965

12 Bartucz Lajos: Antropológiai és személyazonossági vizsgálatok Semmelweis Ignác csontvázán. In: Paleopathológia III. Medicina Kiadó, Budapest, 1966; pp. 521-561.

13 Haranghy László: Semmelweis Ignác betegsége kórbonctani szempontból. Országos Orvostörténeti Könyvtár Közleményei, 1960; 18: 29-36.

14 Regöly-Mérei Gyula: Semmelweis Ignác betegsége orvostörténeti megvilágításban. Országos Orvostörténeti Könyvtár Közleményei, 1960; 18: 13-28.

15 Regöly-Mérei Gyula: Semmelweis betegségének patológiai rekonstrukciója a katamnesztikus elemzés és paleopatológiai vizsgálat alapján. Orvostörténeti Közlemények, 1970; 55-56: 37-64. jelent könyve ${ }^{16}$, amely rendkívüli alapossággal, elemző módon követi nyomon Semmelweis életútját, elemzi és értelmezi munkásságát, kora orvostudományát, feltárja azokat az okokat, ami miatt Semmelweis kortársai nem értették a gyermekágyi lázzal kapcsolatos felismerését. Ezzel az elemző módszerrel tárja fel Semmelweis utóéletét, a halálát követô majd száz esztendô szakmai történéseit.

Az 1970-es évek Semmelweisszel kapcsolatos eseménye, amikor Silló Seidl Györgynek sikerült Bécsből megszereznie Semmelweis eredeti boncjegyzőkönyvét és egy szakmai bizottság megkísérelte végleg meghatározni a halál okát. Silló Seidl megjelentette - magyarul és németül egyaránt - Az igazság Semmelweis halála körül címú könyvét, amelyben Semmelweis magyar barátait és pályatársait azzal vádolta meg, hogy „összeesküdtek” Semmelweisszel szemben, a bécsi elmegyógyintézetbe záratták, ahol meggyilkolták. Sajnos e téves felvetésnek ma is vannak követői, időről időre visszatér a bulvársajtóban. A német nyelvü szakirodalomban jelentős munka Karl Semmelweis Ignaz Philipp Semmelweis, Retter der Mütter címú, közel 500 oldalas könyve, amely gazdag szakirodalomra, levéltári kutatásokra épülve írja meg Semmelweis életét és munkásságát. A szerző munkájában felhasználta édesapja, id. Semmelweis Károlynak, a jeles múvelődéstörténésznek családtörténeti kutatásait is. Ez a genealógiai munka egészen 1570-től követi nyomon a Semmelweis család mindegyik ágának történetét. Ez abból a szempontból is lényeges, mivel a hazai szakirodalom már figyelmen kívül hagyta a burgenlandi Semmelweis család 19-20. századi történetét.

Az elmúlt két évtized Semmelweis-irodalmának jeles munkája az orvosgenetikus Czeizel Endre Tudósok, gének, tanulságok. A magyar természettudós géniuszok családfaelemzése (Galenus Kiadó, 2006) címú könyve, amelyben a tehetség szempontjából vizsgálja a tabáni Semmelweis családot, illetve Semmelweis Ignác leszármazottait. Családtörténeti szempontból lényeges Kapronczay Károly A Semmelweis család története (Semmelweis Kiadó, 2008) címú kötete, amely nem kizárólag Semmelweis Ignácra összpontosít, hanem a kismartoni, zirci, tabáni családokra is, amelyek közül csak a kismartoni és a tabáni Semmelweiseket köti össze a vérrokonság.

(Kapronczay Károly dr., e-mail: k.kapronczay@freestart.hu)

${ }^{6}$ Benedek István: Semmelweis és kora. 2. bővített kiadás. Gondolat Kiadó, Budapest, 1973. 